\title{
Comparative gene expression profiling during in vitro regeneration in two coconut cultivars
}

\author{
Udyawar Bhavyashree, Kaitheri Edathil Rachana, Kooliyat Lakshmi Jayaraj, Muliyar Krishna Rajesh, \\ Karun Anitha*
}

Division of Crop Improvement, ICAR-Central Plantation Crops Research Institute, Kasaragod 671124, Kerala, India.

\section{A B S T R A C T}

\begin{abstract}
A comparative study of gene expression patterns during different stages of in vitro regeneration in two coconut cultivars viz. WCT (West Coast Tall) and COD (Chowghat Orange Dwarf) was carried out in this study. Calli were obtained from shoot meristem explants and expression patterns of eight genes at different development stages in the two cultivars were analyzed using RT-qPCR. The results revealed the enhanced expression of $P K L, S E R K$ and WUS in embryogenic calli compared to non-embryogenic calli. High expression of GLP, ECP and GST could be observed in normal somatic embryos compared to abnormal somatic embryos. Enhanced expression of ECP, LEAFY, GLP and WRKY could be observed in normal meristemoids compared to aberrant meristemoids. When the two cultivars were compared, higher somatic embryogenesis was noticed in WCT as compared to COD. Embryogenic calli of WCT showed higher expression of SERK, $P K L$ and WUS compared to COD. Somatic embryos of WCT showed high expression of GLP and GST compared to COD, where as for ECP gene, higher expression was observed in WCT compared to COD. In cases of WRKY and LEC, higher levels of expression were observed in WCT meristemoids when compared to COD. The results revealed significant differences in regeneration potential and gene expression patterns in the two coconut cultivars suggesting genotypic differences of cultivars to in vitro culture.
\end{abstract}

Keywords: Coconut; Gene expression; Recalcitrance; Shoot meristem; Somatic embryogenesis

\section{INTRODUCTION}

The coconut palm (Cocos nucifera L.), belonging to the family Arecaceae, is a very important crop in tropical areas. Crop improvement in coconut is difficult and time consuming due to its long tree pre-bearing age, high heterozygosity, long interval between generations and exclusively seed propagated nature (Arunachalam and Rajesh, 2008; Rajesh et al., 2014a). Since the availability of superior quality planting material is essential for crop improvement, tissue culture is considered as an important tool for the rapid multiplication of elite coconut genotypes (Fernando et al., 2010). Unfortunately, coconut is a highly recalcitrant species with respect to tissue culture. Many explants have been tested, including immature inflorescence (Branton and Blake, 1984), immature embryos (Gupta et al., 1984), immature leaves (Raju et al., 1984; Buffard-Morel et al., 1992) and the results obtained indicate that regeneration can be achieved, but is rather difficult. Somatic embryos, developed from plumular explants, were capable of germination and subsequent development into plantlets, which could be successfully transferred to nursery (Chan et al., 1998; Rajesh et al., 2005, 2014a).

Somatic embryogenesis, which forms the basis of cellular totipotency, consists of various developmental stages of somatic cells towards the embryogenic pathway (Chugh and Khurana, 2002). Induction of embryogenic calli is the critical step for the success of plant regeneration and this depends on medium condition, growth regulators, seasonal variation etc (Rachmawati and Anzai, 2006). Some of the major bottlenecks in somatic embryogenesis in coconut include lower rate of formation of somatic embryos, dissimilar response of various explants, abnormalities and poor establishment of in vitro regenerated plants (Fernando et al., 2010).

Somatic cells attain embryogenic potential by reprogramming of gene expression (Chugh and Khurana, 2002; Solis-Ramos et al., 2012). Various genes are induced

\footnotetext{
${ }^{*}$ Corresponding author:

Anitha Karun, Division of Crop Improvement, ICAR-Central Plantation Crops Research Institute, Kasaragod 671124, Kerala, India.

E-mail: anithakarun2013@gmail.com
}

Received: 21 January 2016;

Revised: 29 May 2016;

Accepted: 03 June 2016;

Published Online: 23 June 2016 
during somatic embryogenesis which results in the synthesis of new mRNA and proteins; some of well-studied genes include SERK (Somatic Embryogenesis Receptor Kinase), LEC (Leafy Cotyledon), GLP (Germin-like Protein), GST (Glutathione-S-transferase), ECP (Extracellular Protein), WUS (Wuschel) and PKL (Pickle) (Solis-Ramos et al., 2012; Smertenko and Bozhkor, 2014).

In recalcitrant species such as coconut, the differential gene expression studies during somatic embryogenesis are limited and focussed on a few genes like cyclin-dependent kinase gene (CDKA) (Montero-Cortes et al., 2010a), KNOTTEDlike homeobox gene (Montero-Corte et al., 2010b) and SERK gene (Perez-Nunez et al., 2009). In coconut, transcriptome analysis of embryogenic calli derived from plumular explants of West Coast Tall (WCT) cultivar resulted in the identification of fourteen genes; the expression patterns of these genes were validated in six development stages using RT-qPCR (Rajesh et al., 2015). Studies on changes in gene expression patterns during maintenance of embryogenic potential of calli in WCT palms have also been carried out and differential expression patterns were noticed in two stages vi\%, initial embryogenic calli (21 days old) and long term embryogenic calli (21 week old) (Bhavyashree et al., 2015). As an extension of these two work, the present study was undertaken to compare the culture response from shoot meristem explants and gene expression patterns during various in vitro developmental stages in two cultivars of coconut, a tall and a dwarf, using RT-qPCR. We have also conducted a comparative study on gene expression patterns in embryogenic and non-embryogenic calli in these two cultivars, which forms the first such study in coconut.

\section{MATERIALS AND METHODS}

\section{Plant material}

Harvesting of matured nuts, aged 11-12 months old, was carried out in two cultivars vir., West Coast Tall (WCT) and Chowghat Orange Dwarf (COD) from palms located at farm at ICAR-CPCRI, Kasaragod, Kerala, India. The nuts were dehusked and cut open and embryos with endosperm were excised using a cork borer, placed in distilled water and taken to the laboratory. In a laminar air-flow chamber, the endosperm plugs containing the embryos were washed with $0.01 \% \mathrm{HgCl}_{2}$ for 5 minutes and rinsed 3-4 times with sterile distilled water to remove the traces of $\mathrm{HgCl}_{2}$. Later, excision of the embryos was carried out from the endosperm plugs, the embryos were surface sterilized with $20 \%$ sodium hypochlorite $\mathrm{NaClO}$ solution for 20 minutes and subsequently washed for 5-6 times with sterile distilled water. Shoot meristems were then excised from the sterilized embryos and inoculated in to callus induction medium.

\section{Callus induction and somatic embryogenesis}

For callus induction, the plumular tissues were inoculated into full strength Y3 basal medium (Eeuwens, 1976) supplemented with 2,4-dicholorophenoxyacetic acid (2,4-D, 74.6 $\mu \mathrm{M}$ ), Thidiazuron (TDZ, $4.5 \mu \mathrm{M}$ ), sucrose (87.6 mM) and charcoal (1 g/l) (Rajesh et al., 2005). After adjusting the $\mathrm{pH}$ to 5.8 , the medium was autoclaved at $121^{\circ} \mathrm{C}$ for $20 \mathrm{~min}$. The excised shoot meristem explants were inoculated into callus induction media and kept for incubation in dark at $27+2^{\circ} \mathrm{C}$. The initial calli obtained were subcultured into media supplemented with gradually reducing concentrations of 2,4-D $(45.24 \mu \mathrm{M}$ and then to $22.6 \mu \mathrm{M}$ ) in the later stages. A polyamine (spermine, 50 $\mu \mathrm{M}$ ) and a cytokinin (TDZ, $4.5 \mu \mathrm{M}$ ) were also incorporated in this medium for better multiplication of callus in embryogenic stage. Hormone-free Y3 basal medium supplemented with high concentration of charcoal $(2.5 \mathrm{~g} / \mathrm{l})$ was used for maturation of somatic embryos. BAP $(22.2$ $\mu \mathrm{M})$ along with glutamine $(34.2 \mu \mathrm{M}), \mathrm{GA}_{3}(2.8 \mu \mathrm{M})$ and 2,4-D $(0.045 \mu \mathrm{M})$ were utilized as regeneration medium (Rajesh et al., 2015; Bhavyashree et al., 2015). BAP was increased gradually (66.6-88.8 $\mu \mathrm{M})$ in later stages for shoot regeneration. High concentration of $\alpha$-naphthalene acetic acid $(200 \mu \mathrm{M})$ was used in the rhizogenesis medium. After two weeks of incubation, plantlets were transferred to a hormone-free medium.

\section{Statistical analysis}

Each treatment was conducted in three replications and designed as Completely Randomized Design (CRD). Around 50 shoot meristems from each cultivar were utilized for each replication. Observations were recorded for embryogenic calli induction, number of somatic embryo formation and number of meristemoids. Observations were also taken for abnormal tissues such as nonembryogenic calli, abnormal somatic embryo and abnormal meristemoids. The results obtained were analyzed in a two way ANOVA by using SAS software. Level of significance was represented by $\mathrm{CD}$ at $5 \%$.

\section{RT-PCR analysis}

Total RNA was extracted from embryogenic calli (60-days old, after second subculture), non-embryogenic calli (60-days old, after second subculture), somatic embryo (150-days old, after fourth subculture), abnormal somatic embryo (150-days old, after fourth subculture), meristemoids (120-days old, after fourth subculture) and abnormal meristemoids (120-days old, after fourth subculture) using Nucleospin RNA plant kit (MachereyNagel) and integrity, concentration and quality check and DNase 1 (Fermentas) treatment were performed. Reverse transcription was performed with High Capacity RNA-tocDNA kit (Life Technologies) using aliquots of total RNA extracted. The cDNA samples were diluted to $20 \mathrm{ng} / \mu \mathrm{l}$. 
The sequences of the selected primers for the eight genes analyzed using RT-PCR studies were considered from a previous study (Rajesh et al., 2015). The reaction mixture for RT-PCR consisted of $2 \mu \mathrm{l}$ of $10 \mathrm{X}$ reaction buffer, 2 $\mu \mathrm{M}$ of each forward and reverses primer, $0.8 \mu \mathrm{l}$ of $10 \mathrm{mM}$ dNTP mix, $1 \mu$ of synthesized cDNA and $1 \mathrm{U}$ of Taq polymerase. RT-PCR reactions were performed using thermal cycler (BIORAD) with the following cycling program: $1 \mathrm{~min}$ at $94^{\circ} \mathrm{C}, 30$ cycles of $30 \mathrm{~s}$ at $94^{\circ} \mathrm{C}, 1 \mathrm{~min}$ at $55^{\circ} \mathrm{C}, 1 \mathrm{~min}$ at $72^{\circ} \mathrm{C}$ and a $10 \mathrm{~min}$ extension at $72^{\circ} \mathrm{C}$, with a negative control.

\section{RT-qPCR}

All RT-qPCR were performed using SYBR Green PCR Master Mix (Applied Biosystems) in Step One ${ }^{\mathrm{TM}}$ Real Time PCR system (Perkin-Elmer Applied Biosystems) with the following standardized conditions: initial holding stage $52^{\circ} \mathrm{C}$ for 2 minutes, $95^{\circ} \mathrm{C}$ for 10 minutes, followed by 40 cycles at $95^{\circ} \mathrm{C}$ for 15 seconds and a final step at $60^{\circ} \mathrm{C}$ for 1 minute (Rajesh et al., 2015). All reactions were carried in triplicates. The relative quantification in gene expressions of somatic embryogenesis receptor-like kinase (SERK), leafy cotyledon (LEAFY), WRKY, wuschel (WUS), extracellular protein $(E C P)$, germin-like protein $(G L P)$, glutathione-stransferase (GST) and pickle (PKL) were determined by means of $2^{-\Delta \Delta C t}$ method (Livak and Schmittgen, 2001) by normalizing to $\alpha$-tubulin, which was used as the internal control gene (Rajesh et al., 2014b).

\section{RESULTS}

\section{Callus induction and somatic embryogenesis}

Excised shoot meristem of WCT and COD showed initial callus induction after 25 days of incubation in dark. Some of the cultures showed severe browning and abnormal growth. The initiated calli were chopped and subcultured to a medium incorporated with 2,4-D $(45.24 \mu \mathrm{M})$, TDZ $(4.5 \mu \mathrm{M})$ and spermine $(50 \mu \mathrm{M})$. Embryogenic calli were formed after 55-60 days of incubation in this media in both WCT and COD cultivars (Fig. 1a and b). Abnormal and compact calli were also formed in some of the cultures in this media. Conversion of embryogenic calli to compact calli was observed in both the cultivars (Fig. 1c and d). Embryogenic calli were multiplied and proembryos were initiated in a medium supplemented with 2,4-D $(22.6 \mu \mathrm{M})$, TDZ $(4.5 \mu \mathrm{M})$ and spermine $(50 \mu \mathrm{M})$.

Proembryos, formed after 120 days of incubation, were inoculated into a hormone-free media for the maturation of somatic embryo. From Table 1, it is evident that formation of somatic embryos were more in WCT cultures (Fig. 1e) compared to COD cultures (Fig. 1f; Table 1). Some of the proembryos showed abnormal growth (Fig. 1g and h).
Somatic embryos were subcultured in a regeneration media containing BAP $(22.2 \mu \mathrm{M}), \mathrm{GA}_{3}(2.8 \mu \mathrm{M}), 2,4-\mathrm{D}(0.045 \mu \mathrm{M})$ and glutamine $(34.2 \mu \mathrm{M})$. The gradual increase of BAP $(66.6-88.8 \mu \mathrm{M})$ in later stages of culture resulted in shoot regeneration.

Some of the embryogenic cultures also showed meristemoid type of growth. Meristemoids showed the presence of 4-5 shoot meristems (Fig. 1i and j) whereas some cultures showed abnormal development of meristemoids (Fig. 1k and 1; Table 1). High concentration of $\alpha$-naphthaleneacetic acid $(200 \mu \mathrm{M})$ was used for root initiation in case of meristemoids (Fig. $1 \mathrm{~m}$ ). Abnormal development of shoots were also observed from abnormal meristemoids (Fig. 1n). After two weeks of incubation, plantlets were transferred to hormone-free medium. According to statistical analysis, it was noticed that the response of embryogenic calli, somatic embryo, meristemoid was found to be significant. The formation of embryogenic calli, somatic embryo and meristemoids and abnormal somatic embryo was significantly higher in case of WCT compared to COD. However, percentage of non embryogenic calli and abnormal meristemoids were also high in case of WCT compared to COD, but it was not significant (Table 1).

\section{Gene expression studies}

Total RNA was extracted from embryogenic calli, nonembryogenic calli, somatic embryo, abnormal somatic embryo, meristemoids and abnormal meristemoids of WCT and COD (Fig. 2a and b). The expression patterns of eight genes were analysed in six different stages. RTPCR reaction was used to amplify the eight genes and a specific single PCR product was obtained using the gene specific primers (Fig. 2c). By using the gene specific primers, RT-qPCR was carried out to study the gene expression patterns in different stages of in vitro culture. Amplification plot (Fig. 2d) and melting curve analyses (Fig. 2e) of eight candidate genes in each sample pointed out that the eight primers produced a single PCR amplicon without any non-specificity. It was found that a defined amplification

\begin{tabular}{|c|c|c|c|}
\hline & WCT & COD & CD at $5 \%$ \\
\hline EC & $5.5 \pm 0.73$ & $5.0 \pm 0.79$ & $0.94^{*}$ \\
\hline NEC & $6.62 \pm 0.44$ & $4.82+0.16$ & NS \\
\hline SE & $1.89 \pm 0.8$ & $0.77 \pm 0.05$ & $0.33^{*}$ \\
\hline ASE & $3.45 \pm 0.2$ & $1.45 \pm 0.2$ & $0.48^{*}$ \\
\hline MS & $1.89 \pm 0.1$ & $1.77 \pm 0.25$ & $0.43^{*}$ \\
\hline AMS & $3.45 \pm 0.2$ & $3.21 \pm 0.25$ & NS \\
\hline
\end{tabular}

* Significant at $1 \%$, NS- Non significant 

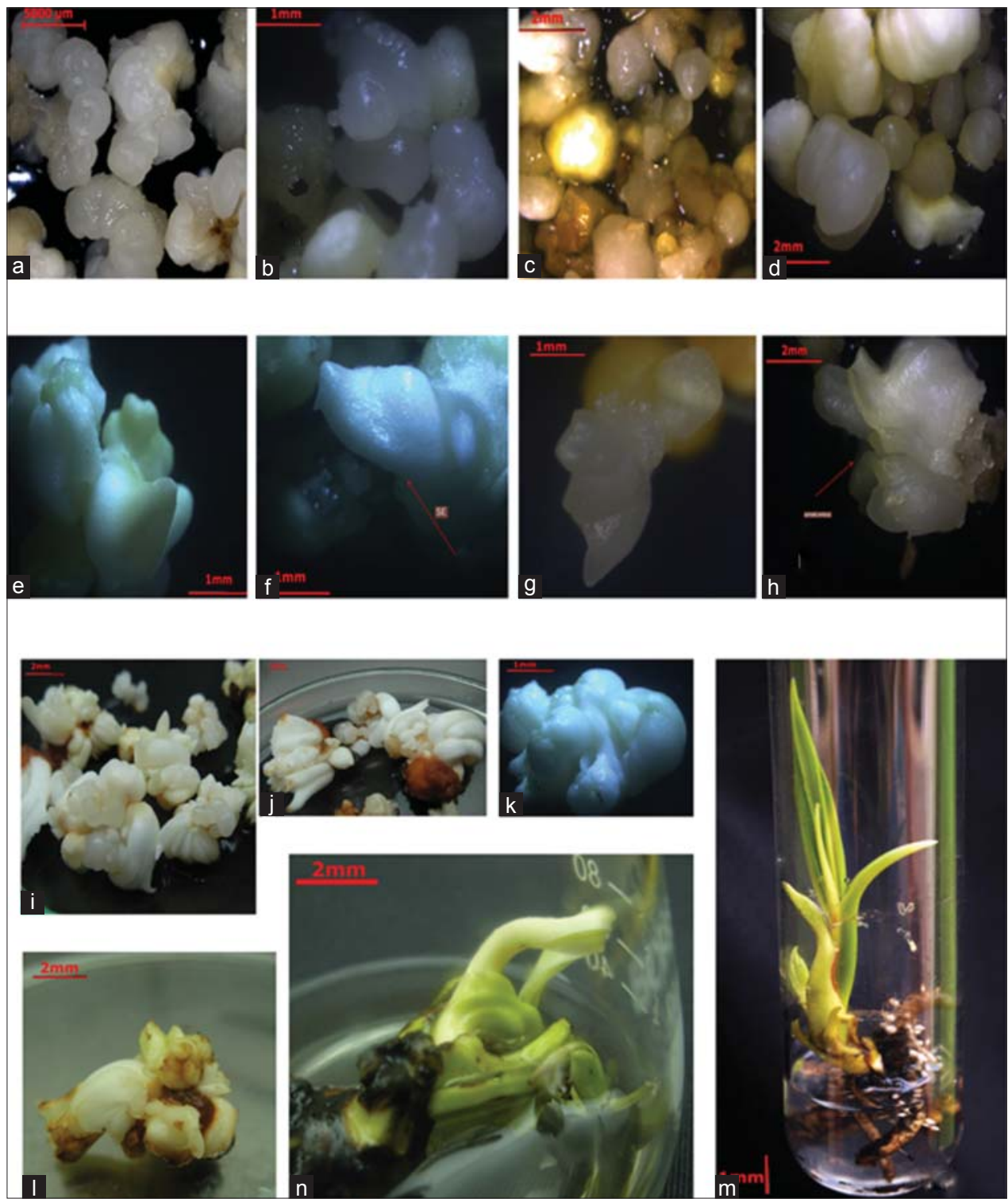

Fig 1. Developmental stages of somatic embryogenesis. (a) Embryogenic calli initiated from WCT (after 60 days), (b)Embryogenic calli initiated from COD (after 60 days), (c) Abnormal embryogenic calli initiated from WCT (after 60 days), (d) Abnormal embryogenic calli initiated from COD (after 60 days). (e) Somatic embryo formation after 150 days of culture incubation from WCT, (f) Somatic embryo formation after 150 days of culture incubation from COD, (g) Abnormal somatic embryo formation after 150 days of culture incubation from WCT, (h) Abnormal somatic embryo formation after 150 days of culture incubation from COD, (i) Meristemoid formation after 150 days of culture incubation from WCT, (j) Meristemoid formation after 150 days of culture incubation from COD, (k) Abnormal development of meristemoids after 150 days of culture incubation from WCT, (I) Abnormal development of meristemoids after 150 days of culture incubation from COD, $(\mathrm{m})$ Plantlet regenerated through in vitro culture, (n) Abnormal development of shoot from abnormal meristemoids.

was observed in all the developmental stages of somatic embryogenesis.

Enhanced expression of PKL, SERK and WUS genes was observed in case of embryogenic calli compared to nonembryogenic calli (Fig. 3a and b). Enhanced expression of ECP gene was observed in somatic embryos of both WCT and COD compared to other genes. In cases of GLP and GST expression was relatively less compared to ECP. A 10fold increase in the activity of ECP gene was noticed in somatic embryo of WCT when compared to COD variety.
In case of abnormal somatic embryos, expression of ECP, GST and GLP was quite low (Fig. 3c and d). In case of meristemoids, LEC expression was enhanced compared to other genes. In case of abnormal meristemoids, there was decreased expression of ECP, GLP and WRKY (Fig. 3e and f). $\alpha$-tubulin real time profiling clearly indicated its stable expression in all the biological samples used for normalizing data.

RT-qPCR analyse was also utilized to compare the expression patterns in the two cultivars. It was also noticed 


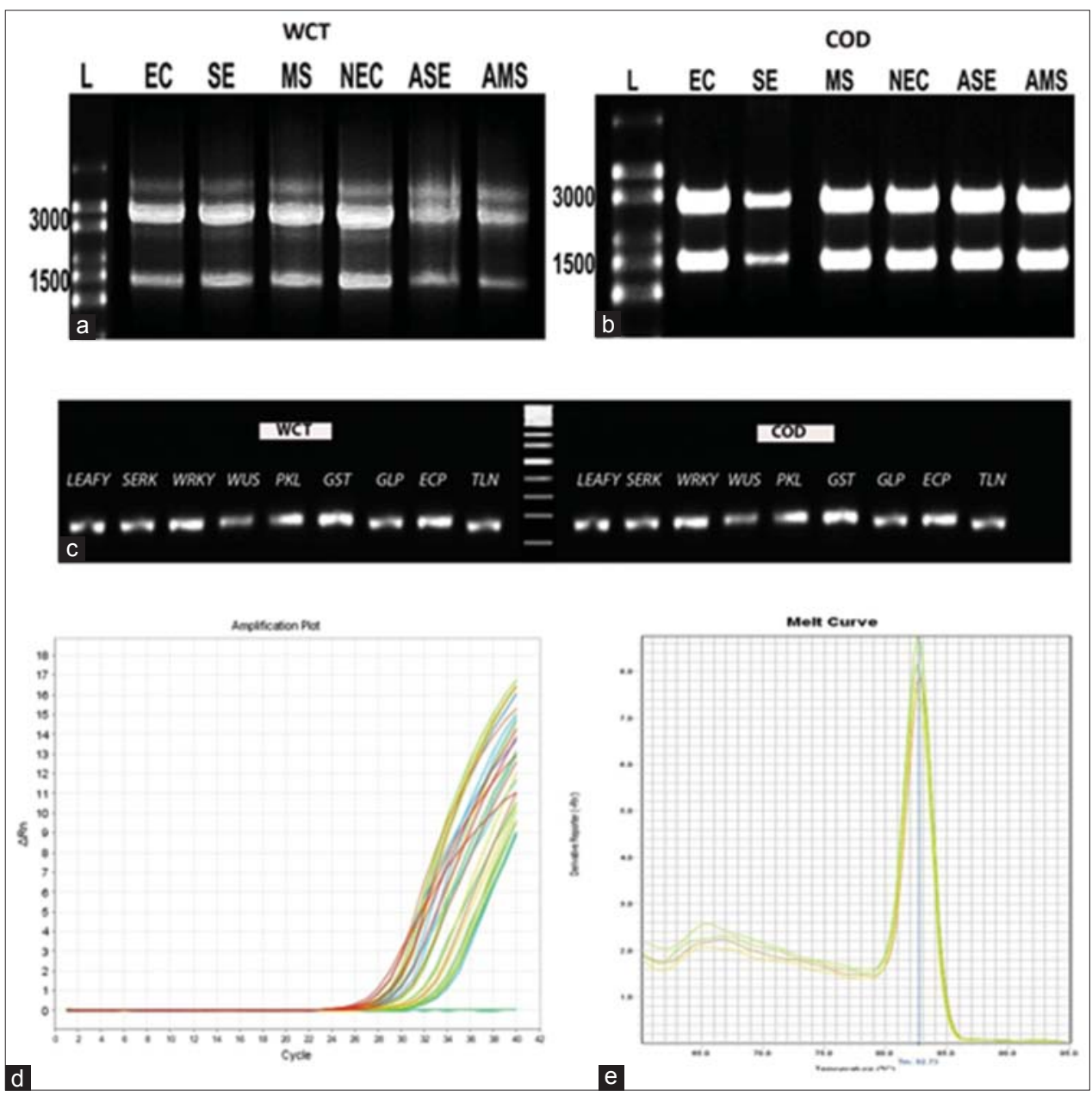

Fig 2. Real-time analysis of pattern of gene expression in different developmental stages of culture. (a) RNA obtained from EC, NEC, SE, ASE, MS, AMS of WCT culture. High range RNA ladder (L), (b) RNA obtained from EC, NEC, SE, ASE, MS, AMS of COD culture. High range RNA ladder (L), (c) RT-PCR gel image of eight genes(Lanes 1-8), $\alpha$-tubulin(Lane 9) and negative control (Lane 10) in WCT and COD, (d) Amplification plot of quantitative RT-PCR analysis of expression of eight genes. (e) Derivative of melt curve analysis of amplicon of eight genes after SYBRgreen real-time assay.

that, embryogenic calli of WCT showed high expression of SERK, PKL and WUS compared to COD. Somatic embryo (150 days old) of WCT showed high expression of ECP, GLP and GST compared to COD. In case of WRKY, $E C P$ and $L E C$ higher levels of expression was observed in meristemoids of both WCT compared to COD.

\section{DISCUSSION}

Somatic embryogenesis is a process wherein somatic cells undergo a chain of morphological, biochemical and molecular modifications resulting in the formation embryogenic cells (Karami et al., 2009). These changes involve differential gene expression patterns which have been reported to possess vital roles in the molecular regulation of the process (Chugh and Khurana, 2002). Coconut is a highly recalcitrant species with respect to tissue culture with somatic embryo formation and plantlet formation being the major bottlenecks yet to be overcome.
Among the different explants, somatic embryos initiated from plumular tissues were found to possess enhanced response potential while considering calli formation and development of embryogenic competence (Hornung 1995; Chan et al., 1998; Oropeza et al., 2005; Rajesh et al., 2005, 2014a). The present study describes a comparative study of induction of embryogenic calli and somatic embryogenesis and pattern of gene expression in various developmental stages of in vitro regeneration derived from shoot meristem explant in two coconut cultivars.

Induction of callogenesis and somatic embryogenesis in coconut requires a strong auxin stimulus, which is achieved by supplementation of 2,4-D in the medium (Hornung, 1995). According to Verdiel and Buffard-Morel (1995) 2,4-D was crucial for both activation as well as division of the undifferentiated cells of explants resulting in callus formation. In the present study, initiation of calli was noticed after 25-days of incubation in medium supplemented with 

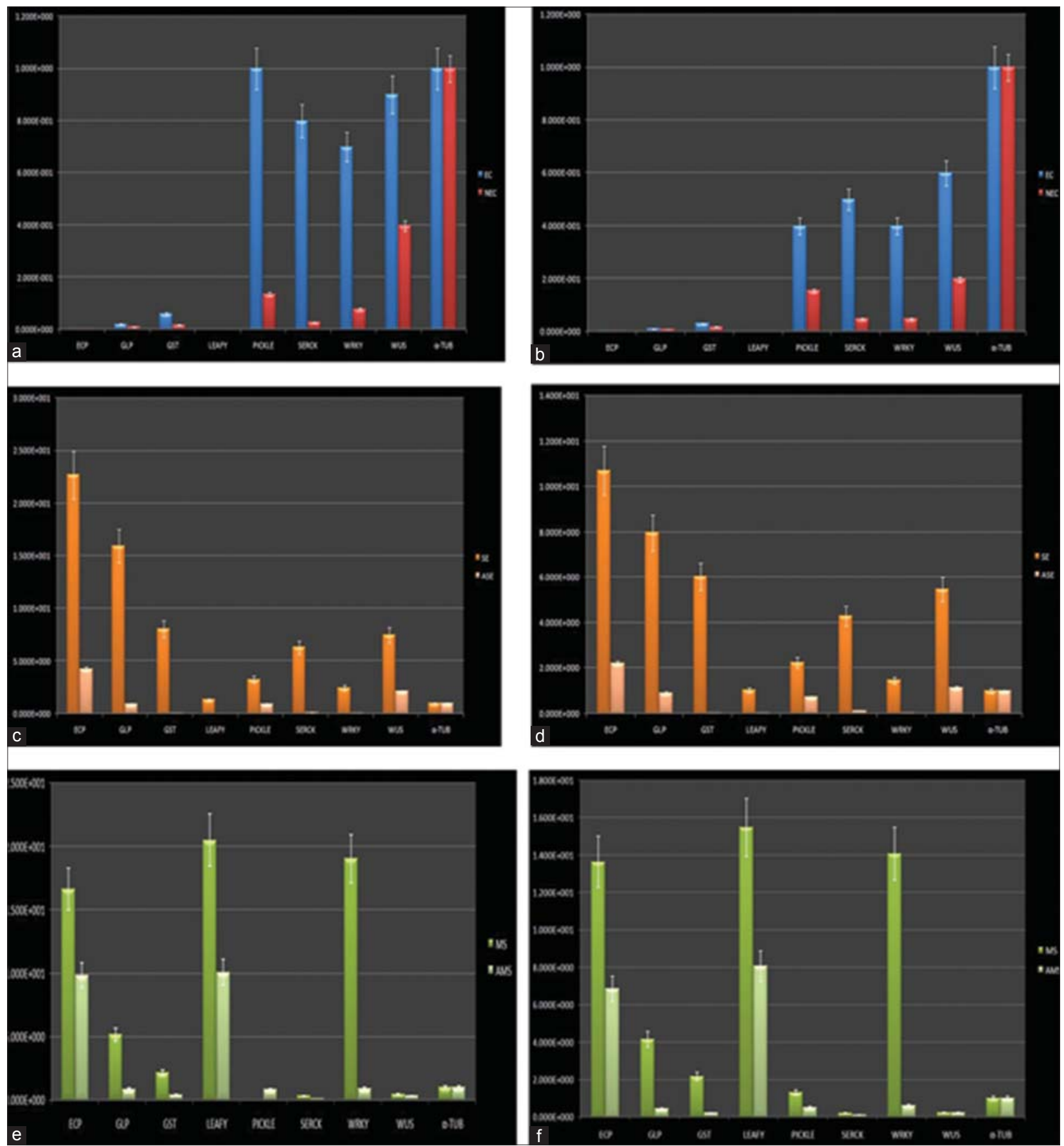

Fig 3. Gene expression levels of eight genes in EC, NEC, SE, ASE, MS, AMS. In graphical representation X axis indicates the eight different genes The $y$-axis indicates normalized mRNA expression (normalized to TUBULIN) relative to control samples. Data were expressed as mean $\pm S E M$. (a) Gene expression level of eight genes in EC and NEC of WCT, (b) Gene expression level of eight genes in EC and NEC of COD, (c) Gene expression level of eight genes in SE and ASE of WCT, (d) Gene expression level of eight genes in SE and ASE of COD, (e) Gene expression level of eight genes in MS and AMS of WCT, (f) Gene expression level of eight genes in MS and AMS of COD.

24-D (74.6 $\mu \mathrm{M})$ and TDZ $(4.5 \mu \mathrm{M})$. Rajesh et al. (2005) had earlier reported initiation of calli after four weeks of culture incubation from perivascular strands of the leaf primordia from plumular explants utilizing the same medium. We also observed that the use of TDZ in combination with 2,4-D in the initial medium gave enhanced callogenesis, which was in agreement with the results obtained earlier in coconut by Rajesh et al. (2005). Initiated calli were further chopped and inoculated to decreased concentration of 2,4-D. Embryogenic calli started to multiply after 30 days of incubation in this medium.

Proembryo formation was observed from the embryogenic calli after 90 days of culture incubation. Later, these proembryos were transferred to hormone-free media for the maturation of somatic embryo. In case of oil palm, 
embryo development was observed in a hormone-free liquid medium (Touchet et al., 1991). Somatic embryos were subcultured to a media incorporated with BAP $(22.2 \mu \mathrm{M})$ along with glutamine $\left.(34.2 \mu \mathrm{M}), \mathrm{GA}_{3} 2.8 \mu \mathrm{M}\right)$ and 2, 4-D $(0.045 \mu \mathrm{M})$ for regeneration. The gradual increase of BAP (66.6-88.8 $\mu \mathrm{M})$ in later stages resulted in shoot regeneration. However, Chan (1998) used a regeneration medium which was supplemented with 2,4-D $(1 \mu \mathrm{M})$ and BAP $(50 \mu \mathrm{M})$, and reported that germination of somatic embryo was observed after three months of incubation.

Somatic embryo maturation is commonly accomplished with growth regulator-free medium in many crops. However, in coconut, workers have reported that once the nodular calloids were formed, the gradual reduction in the auxin concentration with a corresponding increase in the cytokinin level in the subsequent subculture was necessary for initiation and development of embryoids. The reduction in auxin level has to be gradual and in a controlled manner to achieve balanced development of plantlet with a well organized shoot meristem and normal adventitious root formation. Sudden removal of auxins resulted in massive development of haustorial tissue and precocious root proliferation at the expense of continued shoot meristem development (Branton and Blake, 1983). In coconut palm somatic embryogenesis, the lowering of 2,4-D concentration followed by addition of BAP was found to be essential for the complete bipolar differentiation of the embryo (Verdeil et al., 1994). Merkle (1995) reported that the supplementation of cytokinins during the histodifferentation phase could compensate for the detrimental effects of auxins on meristem development. In the present study, exogenous supplementation with either cytokinins/polyamines, in the presence of decreasing concentrations of an auxin, was found to be essential for somatic embryo maturation/meristemoidal development and regeneration into normal plantlets. The auxin-cytokinin/ polyamine interaction might have had a decisive effect on the hormonal regime of explant proliferation and eventual embryogenesis/organogenesis in coconut. Ammirato (1987) pointed out that normal development of somatic embryos required a fine temporal and spatial regulation of cell division, enlargement and differentiation. Growth regulators may exert multiple effects in these processes depending on the concentration or on the embryo stage at the time of application.

Quantitative RT-PCR data analysis were done to study genes which were expressed during various developmental stages of embryogenic calli and somatic embryo. However, the RT-qPCR gene expression were carried out in case of Cichorium intybus by Delporte et al. (2015). In his study, validation of reference genes for quantitative realtime PCR analysis of gene expression was described to understand the biochemical pathway. They identified the best reference gene i.e., Clath (Clathrin adaptator complex subunit) by using real-time PCR. In case of Jute, the realtime PCR was carried out to analyze the gene expression under stress treatments (Niu et al., 2015). From this study, reference genes for biotic and $\mathrm{NaCl}$ stress i.e., $A C T 7$ and $\mathrm{R} A N$ were screened to normalize the data and for gene expression study, under PEG stress, UBC and DnaJ were recommended. In case of cassava, reference genes were validated for relative gene expression by using RT-qPCR (Hu et al., 2006). From this study, it was revealed that, under specific conditions, varieties, hundreds of genes in the genome of cassava showed low level of expression than traditional reference gene. Higher expression of ECP gene was noticed in somatic embryos of both WCT and COD, compared to rest of the tissues. Enhanced activity of ECP was reported during the torpedo stage of somatic embryo in case of carrot (Kiyosue et al., 1992) and Arabidopsis (Yang et al., 1996). High expression of GLP was seen in case of somatic embryo, in case of embryogenic calli it was comparatively less, but in other explants, its expression was quite low. Earlier studies reported the presence of GLPs in the extracellular compartment of stage-one somatic embryos as demonstrated by David et al. (1996). However, in case of wheat, GLP genes were often expressed during callus stage (Caliskan et al., 2004) and early stages of somatic embryos (Thompson and Lane, 1980).

Somatic embryos of WCT and COD showed the higher expression of GST which was quite low in rest of the tissues. However, abundant expression of GST was noticed during auxin induction and somatic embryogenesis in grape, which was suggested that GST gene plays an important role to accomplish the embryogenic competence (Malabadi et al., 2013). In case of cichorium, GST gene was linked to early stages of somatic embryogenesis (Galland et al., 2007). Increased activity of $L E C$ was observed in the meristemoids of both WCT and COD. In case of somatic embryo, expression was comparatively less. In contrast to these results, Ledwon et al. (2009) reported increased activity of $L E C$ during somatic embryogenesis compared to other developmental stages in Arabidopsis. However it was reported that during early embryogenesis $L E C$ genes are mandatory to identify suspensor cell fate and cotyledon in Arabidopsis (West et al., 1994).

Embryogenic calli of both WCT and COD showed enhanced expression of PKL. PKL gene has earlier been reported to be a part of gibberellin-modulated developmental switch which functions during germination and it causes transcriptional repression of genes coding for leafy cotyledon (LEC) and seed storage proteins. Thus it ensured that traits which are expressed during embryogenesis are not expressed after germination (Ogas et al., 1999; Nolan et al., 2006). 
Embryogenic calli of both WCT and COD showed the higher expression of SERK compared to other stages. In an earlier study in coconut (Perez-Nunez et al., 2009), increased expression of a SERK gene, CnSERK, was seen to occur in meristematic centers, where the embryogenic structures were formed the somatic embryos eventually, thus suggesting that CnSERK expression could be utilized as a marker to check the cell competence to initiate somatic embryos in coconut tissues cultured in vitro. Furthermore, it has been reported that in case of cocoa, TcSERK was highly expressed in embryogenic tissues as well as zygotic and somatic embryos (Marcelo et al., 2005). In carrot cell suspension culture, $S E R K$ functioned in a signal transduction pathway early in the somatic embryo formation (Schmidt et al., 1997). SERK gene has been considered as a characteristic marker to differentiate non-competent embryogenic cells from competent cells (Chugh and Khurana, 2002).

Higher expression of $W R K Y$ was observed in the meristemoids of both WCT and COD compared to somatic embryo and embryogenic calli. However, Rensing et al. (2005) reported enhanced expression of $W R K Y$ during somatic embryogenesis in Cyclamen persicum. Embryogenic calli of both WCT and COD showed increased expression of WUS compared to somatic embryo. Similar results were reported by Ying et al. (2009) in Arabidopsis where the high expression of WUS could be observed in the case of embryogenic callus compared to somatic embryos. Ectopic expression of WUS has also been reported to support vegetative to embryogenic conversion in Arabidopsis (Zuo et al., 2002).

\section{CONCLUSION}

From the above study, it was revealed that in embryogenic calli there is an enhanced expression of PKL, SERK and WUS compared to other stages. High expression of ECP, GST and GLP could be observed in somatic embryos whereas meristemoids showed high expression of $W R K Y$ and LEC. When the two cultivars were compared, embryogenic calli of WCT showed higher expression of SERK, PKL and WUS compared to COD. Somatic embryo of WCT showed high expression of GST and GLP compared to COD. In case of $W R K Y$ and $L E C$, high levels of expression were observed in meristemoids of WCT compared to COD. These genes could therefore be useful as developmental markers for somatic embryogenesis in coconut in particular. These results suggest existence of genotypic differences in regeneration potential and gene expression patterns in coconut.

\section{ACKNOWLEDGEMENT}

The authors are thankful to ICAR for funding.

\section{Author contributions}

All authors contributed equally in this article.

\section{REFERENCES}

Ammirato, P.V. 1987. Organizational events during somatic embryogenesis. In: Green, C. E., D. A. Somers, W. P. Hackett and D. D. Biesboer, (Eds.), Plant Tissue and Cell Culture, AR Liss, New York, Pp. 57-81.

Arunachalam, V. and M. K. Rajesh. 2008. Breeding of coconut palm (Cocos nucifera L.). In: CAB Reviews: Perspectives in Agriculture, Veterinary Science, Nutrition and Natural Resources No. 053. DOI: 10.1079/PAVSNNR20083053.

Bhavyashree, U., K. Lakshmi Jayaraj, K. E. Rachana, K. S. Muralikrishna, K. K. Sajini, M. K. Rajesh and K. Anitha. 2015. Maintenance of embryogenic potential of calli derived from shoot meristem of West Coast Tall cv. of coconut (Cocos nucifera L.). J. Plant. Crops. 43(2): 105-116.

Branton, R. L. and J. Blake. 1983. Development of organized structures in callus derived from explants of Cocos nucifera $\mathrm{L}$. Ann. Bot. 52: 673-678.

Branton, R. L. and J. Blake. 1984. Clonal propagation of coconut palm. In: Pushparajah, E. and C. P. Soon, (Eds.), Cocoa and Coconuts: Progress and Outlook. Incorporated Society of Planters, Kuala Lumpur, Pp. 771-780.

Buffard-Morel, J., J. L. Verdeil and C. Pannetier. 1992. Embryogenese Somatique du cocotier (Cocos nucifera L.) a partir de tissue foliaries etude histologique. Can. J. Bot. 70: 735-741.

Caliskan, M., M. Turet and A. Cuming. 2004. Formation of wheat (Triticum aestivum L.) embryogenic callus involves peroxidegenerating germin-like oxalate oxidase. Planta 219 : 132-140.

Chan, J. L., C. Talavera, R. Hornung, M. Robert and C. Oropeza. 1998. Regeneration of coconut (Cocos nucifera L.) from plumule explants through somatic embryogenesis. Plant. Cell. Rep. 17: 515-521.

Chugh, A. and P. Khurana. 2002. Gene expression during somatic embryogenesis-recent advances. Curr. Sci. India. 83: 715-730.

David, H., J. M. Domon, G. Neutelings and A. David. 1996. Identification of an early marker of embryogenesis in pine. Forest. Sci. 49: 29-39.

Eeuwens, C. J. 1976. Mineral requirementsfor growth and callus initiation of tissue explants excised from mature coconut (Cocos nucifera L.) and date (Phoenix dactylifera L) palms cultured in vitro. Physiol. Plantarum. 36: 23-28.

Fernando, S. C., V. R. M. Vidhanaarachchi, L. K. Weerakoon and S. E. Santha. 2010. What makes clonal propagation of coconut difficult? Asia-Pac. J. Mol. Biol. 18: 163-165.

Galland, R., B. Randoux, J. Vassuer and J. L. Hilbert. 2001. A glutathione-S-transferase cDNA identified by mRNA differential display is upregulated during somatic embryogenesis in Cichorium. BBA - Gene. Struct. Exp. 1522(3): 212-216.

Gupta, P. K., S. V. Kendukar, V. M. Kulkarni, V. Shirgurkar and A. F. Mascarenhas. 1984. Somatic embryogenesis and plants from zygotic embryos of coconut (Cocos nucifera L.) in vitro. Plant. Cell. Rep. 3: 222-225.

Hornung, R. 1995. Micropropagation of Cocos nucifera L. from plumular tissue excised from mature zygotic embryos. Plant. Rech. Dev. 2: 38-41.

Karami, O., B. Aghavaisi and A. M. Pour. 2009. Molecular aspects of somatic to embryogenic transition in plants. J. Chem. Biol. 2: $177-190$. 
Kiyosue, T., K. Yamaguchi-Shinozaki, K. Shiunozaki, K. Higashi, S. Satoh, H. Kamada and H. Harada. 1992. Isolation and characterization of a cDNAthat encodes ECP31, an embryogeniccell protein from carrot. Plant. Mol. Biol. 19: 239-249.

Ledwon, A. and D. G. Malgorgata. 2009. Leafy-cotyledon2 gene expression and auxin treatment in relation to embryogenic capacity of Arabidopsis somatic cells. Plant. Cell. Rep. 28: 1677-1688.

Livak, K. J. and T. P. Schmittgen. 2001. Analysis of relative gene expression data using real-time quantitative PCR and the $2^{-\Delta \Delta C} T$ method. Methods. 25: 402-408.

Malabadi, R. B., K. C. Raju, T. M. Neelambika, S. M. Gangadhar, K. Nataraja, S. K. Vijaya, K. N. Venugopala and O. Bharti. 2013. Detection of glutathione-S -transferase (GST 2, GST3) during the induction of somatic embryogenesis in grape (Vitis vinifera L.). Res. Biotechnol. 4(1): 1-11.

Marcelo de, O. S., R. Eduardo, S. C. Y. Kal, L. P. T. Maria, B. A. D. Barbara and J. L. A. Francisco. 2005. Characterization of the cacao somatic embryogenesis receptor-like kinase (SERK) gene expressed during somatic embryogenesis. Plant. Sci. 168: 723-729.

Merkle, S. A., W. A. Parrott and B. S. Flinn. 1995. Morphogenic aspects of somatic embryogenesis. In: T. A. Thorpe (Ed.), In vitro Embryogenesis in Plants, Kluwer Academic, Dordrecht, Netherlands, Pp. 155-203.

Montero-Cortes, M., F. Rodriguez-Paredes, C. Burgeff, T. PerezNunez, I. Cordova, C. Oropeza, J. L. Verdeil and L. Saenz. 2010a. Characterization of a cyclin-dependent kinase (CDKA) gene expressed during somatic embryogenesis of coconut palm. Plant. Cell. Tiss. Organ. 102: 251-258.

Montero-Cortes, M., L. Saenz, I. Cordova, A. Quiroz, J. L. Verdiel and C. Oropeza. 2010b. GA3 stimulates the formation and germination of somatic embryos and the expression of a KNOTTED-like homeobox gene Cocos nucifera L. Plant. Cell. Rep. 29: 1049-1059.

Nolan, K. E., N. A. Saeed and R. J. Rose. 2006. The stress kinase gene MtSK1 in Medicago truncatula with particular reference to somatic embryogenesis. Plant. Cell. Rep. 25: 711-722.

Ogas, J., S. Kaufmann, J. Henderson and C. Somerville. 1999. PICKLE is a CHD3 chromatin-remodeling factor that regulates the transition from embryogenic to vegetative development in Arabidopsis. In: Proceedings of the National Academy of Science USA. Vol. 96. Pp. 13839-13844.

Oropeza, C., E. Rillo, V. Houcher and J. L. Verdeil. 2005. Coconut micropropagation. In: Batugal, P., V. R. Rao and J. Oliver, (Eds.), Coconut Genetic Resources. IPGRI-APO, Serdang, Pp. 334-346.

Perez-Nunez, M. T., R. Souza, L. Saenz, J. L. Chan, J. J. ZunigaAguilar and C. Oropeza. 2009. Detection of SERK-like gene in coconut and analysis of its expression during the formation of embryogenic callus and somatic embryos. Plant. Cell. Rep. 28: 11-19.

Rachmawati, D. and H. Anzai. 2006. Studies on callus induction, plant regeneration and transformation of Javanica rice cultivars. Plant Biotechnol. 23: 521-524.

Rajesh, M. K., E. Radha, K. K.Sajini, K. Anitha and V. A. Parthasarathy. 2005. Plant regeneration through organogenesis and somatic embryogenesis from plumular explants of coconut (Cocos nucifera L.). J. Plant. Crops. 33(1): 9-17.

Rajesh, M. K., E. Radha, K. K. Sajini and A. Karun. 2014a. Polyamineinduced somatic embryogenesis and plantlet regeneration in vitro from plumular explants of dwarf cultivars of coconut (Cocos nucifera L.). I. J. Agric. Sci. 84(4): 527-530.
Rajesh, M. K., T. P. Fayas, S. Naganeswaran, K. E. Rachana, U. Bhavyashree, K. K. Sajini and A. Karun. 2015. De novo assembly and characterization of global transcriptome of coconut palm (Cocos nucifera L.) embryogenic calli using Illumina paired-end sequencing. Protoplasma. DOI: 10.1007/ s00709-0150856-8.

Rajesh, M. K., K. E. Rachana, T. P. Fayas, M. Babu, A. G. Kiran and A. Karun. 2014b. Selection and validation of reference genes for quantitative gene expression studies by real-time PCR in coconut. In: Muralidharan, K., M. K. Rajesh, K. S. Muralikrishna, V. Jesmi and S. Jayasekhar, (Eds.), National Seminar on Sustainability and Profitability of Coconut, Arecanut and Cocoa Farming - Technological Advances and Way Forward. CPCRI, Kasaragod, TS1-PP5, p. 34.

Raju, C. R., P. P. Kumar, M. Chandramohan and R. D. Iyer. 1984. Coconut plantlets from leaf tissue cultures. J. Plant. Crops. 12: $75-78$.

Rensing, S. A., D. Land, E. Schumann, R. Reski and A. Hohe. 2005. EST sequencing from embryogenic Cyclamen persicum cell cultures identifies a high proportion of transcripts homologous to plant genes involved in somatic embryogenesis. J. Plant. Growth. Regul. 24: 102-115.

Schmidt, E. D. L., F. Guzzo, M. A. J. Toonen and S. C. Vries. 1997. A leucine-rich repeat containing receptor-like kinase marks somatic plant cells component to form embryos. Development. 124: 2049-2062.

Smertenko, A. and P. V. Bozhkov. 2014. Somatic embryogenesis: Life and death processes during apical-basal patterning. J. Exp. Bot. DOI: $10.1093 / \mathrm{jxb} / \mathrm{eru005.}$

Solis-Ramos, L. Y., A. A. Torres, C. L. A. Saenz, S. C. M. Oropeza and E. C. Sernal. 2012. Somatic embryogenesis in recalcitrant plants. In: S. Kenichi, (Ed.), Embryogenesis. InTech, Croatia, Pp. 597-618.

Thompson, E. W. and B. G. Lane. 1980. Relation of protein synthesis imbibing wheat embryos to the cell-free translational capacities of bulk mRNA from dry and imbibing embryos. J. Biol. Chem. 255: 5965-5970.

Touchet, B. de, Y. Duval and C. Pannetier. 1991. Plant regeneration from embryogenic suspension cultures of oil palm (Elaeis guineensis Jacq.) Plant. Cell. Rep. 10: 529-532.

Verdeil, J. L., C. Huet, F. Grosdemange and J. Buffard-Morel. 1994. Plant regeneration from cultured immature inflorescences coconut (Cocos nucifera L.): Evidence for somatic embryogenesis. Plant. Cell. Rep. 13: 218-221.

Verdeil, J. L. and J. Buffard-Morel. 1995. Somatic embryogenesis in coconut (Cocos nucifera L). In: Y. P. S. Bajaj, (Ed.), Somatic Embryogenesis and Synthetic Seeds I, Biotechnology in Agriculture and Forestry. Vol. 30. Spring-Verlag, Berlin, Pp. 299-317.

West, M. A. L., Y, K. L. Matsudaira, J. J. Danao, J. L. Zimmerman, R. L. Fischer, R. B. Goldberg and J. J. Harada. 1994. LEAFY COTYLEDON is an essential regulator of late embryogenesis and cotyledon identity in Arabidopsis. Plant. Cell. 6: 1731-1745.

Yang, H., T. Saitou, Y. Komeda, H. Harada and H. Kamada. 1996. Late embryogenesis abundant protein in Arabidopsis thaliana homologous to carrot ECP31. Physiol. Plant. 98: 661-666.

Ying, H, X. Y. Su, Y. B. Zhao, C. L. Liu, S. D. Zhang, O. Neill and S. Z. Xian. 2009. Auxin-induced WUS expression is essential for embryonic stem cell renewal during somatic embryogenesis in Arabidopsis. Plant. J. 59: 448-460.

Zuo, J., Q. W. Niu, G. Frugis and N. H. Chua. 2002. The WUSCHEL gene promotes vegetative-to-embryogenic transition in Arabidopsis. Plant. J. 30: 349-359. 